\title{
Environmental Safety and Security Investigations of Neustonic Microplastic Aggregates Near Water-Air Interphase
}

\author{
Ashok Vaseashta ${ }^{1 *}$, Volodymyr Ivanov², Viktor Stabnikov ${ }^{2}$, Andriy Marinin $^{2}$ \\ ${ }^{1}$ International Clean Water Institute, Manassas, VA USA, Riga Technical University, Kalku Street, Riga, Latvia, \\ and Ghitu Institute of Electronic Engineering and Nanotechnologies, Academiei str., 3/3, Chisinau, Moldova \\ ${ }^{2}$ National University of Food Technologies, 68 Volodymyrska Str., Kyiv 01601, Ukraine
}

Received: 30 September 2020

Accepted: 25 December 2020

\begin{abstract}
Scientific and public concerns due to presence of microplastic debris in the marine and freshwater environment is fueling concerns of its impact on aquatic ecosystems and public health. Major sources of water-polluting microplastics are polyethylene and polypropylene, as they aggregate near the waterair interphase. Such neustonic hydrophobic cells attract spores of bacteria causing adverse impact on the environmental, health and food supply chain. The objectives of this review investigation were to (a): evaluate the concentration of microplastics with the sizes less $100 \mu \mathrm{m}$ floating near the waterair interphase; (b): develop a phenomenological model to study fate and transport of microplastics; (c): analyze microbial coatings, and (d): assess potential impacts of biofilm-coated neustonic microplastics on environment. A thorough review of microplastic pollution in marine environment was conducted in terms of its size distribution, toxicity and toxicokinetic pathways. Since biofilms coated microplastics float near the surface, hydrophobic cells of bacteria typically concentrate within a few micrometers layer of water-air interphase. To develop a phenomenological model of neustonic floating biofilm-coated microplastics, samples with the size of less than $100 \mu \mathrm{m}$ were collected from within a few millimeters near the water-air interphase and were subsequently concentrated using microfiltration of water samples for analysis. Results of the optical scan of hexadecane and bacterial cells formed on vertically submerged microscope slides near water-air interphase are presented. Additionally, microplastics near a thin layer of water-air interphase were investigated using scanning electron microscopy, fluorescentmicroscopy, flow cytometry, and particle analyzers. Since, hydrophobic and putative pathogenic bacteria are attached to water surface, which dominate near water-air interphase, biofilm-coated microplastics are more attractive for consumption by aquatic species than pure microplastics, which significantly increases negative impacts of microplastics on aquatic ecosystems and public health through foodchain supply. We conclude that it is critical to extend this investigation to include safety in terms of
\end{abstract}

*e-mail: prof.vaseashta@ieee.org 
aquatic ecotoxicity, security, risk assessment, life-cycle analysis, upcycling of plastics and policy recommendation on this new category of water pollutant.

Keywords: neustonic, microplastics, environment, safety, security, water-air interphase

\section{Introduction}

\section{Microplastics Pollution in Water}

With ubiquitous increase in applications of plastic, pollution associated with the plastic debris in air, water and landfills and its likely detrimental effects on biota and human health has become one of the most pressing issues globally. In the overall context of plastic use, reuse, recycling, upcycling and circular economy, it is critical to study various aspects of interaction of plastics with our environment, resulting from degradation of discarded plastic debris in rivers, lakes, sea water, municipal and industrial wastewater, urban effluents and land runoff $[1,2]$, as well as in marine environment $[1,3]$. There are numerous studies on the geographical distribution, abundance and adverse effects of microplastics in marine ecosystems, showing that an estimated that the total quantity of waste plastics in the marine environment is $\sim 250$ KTons [3]. Primarily, microplastics are produced due to physical disintegration and chemical or biological degradation of plastic from discarded single-use beverage bottles, cosmetics, plastic-based composites, bags and tableware as they disintegrate into microfibers and microspheres [4] over a period of time. Environmental microplastic debris in rivers and estuaries [5], coastlines [6], sediments [7] and in biota [8] are now considered as an "emerging contaminant vector". Many investigations have focused on the toxicity of microplastics and their potential for pharmaceutical transporting microbiomes in waste waters $[9,10]$. Despite numerous investigations and concerns of microplastics as "contaminants of emerging concern" in freshwater environments [11], there are limited literature on the evaluation of neustonic microplastics $[12,13]$ and their potential harmful impacts from safety, security and sustainability standpoint. Hence, this study was conducted to study neustonic microplastics mechanism, review toxicokinetic pathways and associated concerns of this pollution on marine life.

Currently, discarded plastic waste is being discharged at vastly greater quantities at a rate greater than ever before. The Black Sea region has witnessed significantly increased plastic pollution, because it has an unusually high river discharge into a relatively small semi-enclosed sea and is surrounded by several industrialized countries. The situation is approaching a tipping point of exhausting the resilience of ecosystems with documented high risk to marine animal and endocrinological human health [14]. Recent reports show that plastic debris contribute to the release of toxic

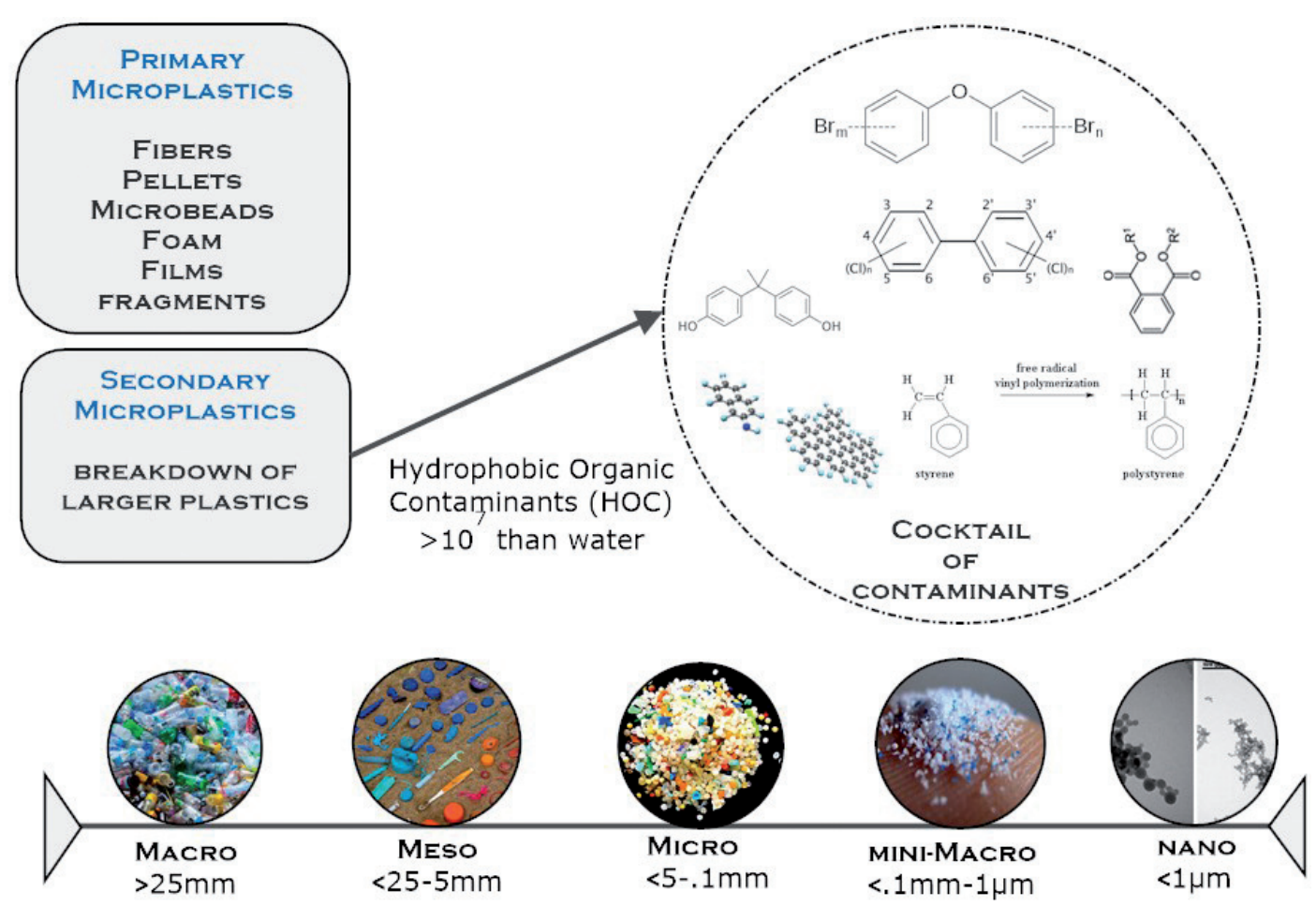

Fig. 1. Size distribution of plastics in marine environments. 
volatile organic compounds (VOCs) [15] and greenhouse gases $(\mathrm{GHG})$ [16], as a potential hazard associated with the environmental weathering and degradation of plastic debris. Thus, the ability to identify, characterize and mitigate both macro and microplastic from the world's marine ecosystem is of paramount importance and is a multifaceted endeavor, requiring a sense of urgency and international cooperation on policies development on fair reporting and limits on use and discarding of plastics. Nexus of technological innovations are necessary before noticeable changes are observed, suggesting that the impact of microplastics may have a longer lasting effect then currently recognized. Globally there are several case studies which provide qualitative and quantitative data of microplastics in aquatic environment. As examples of case studies, the concentrations of microplastics of size $<300 \mu \mathrm{m}$ in surface water of North Shore Channel, Chicago, USA were in the range from 0.7 to 7 particles $/ \mathrm{m}^{3}$, as compared to the concentrations of microplastics of size $<500 \mu \mathrm{m}$ in the surface water of Yangtze River Estuary, China were up to 10,200 particles $/ \mathrm{m}^{3}[17,18]$.

Conventional classes of plastic pollutants are normally classified as follows: $<1 \mathrm{~mm}-1 \mu \mathrm{m}$ (minimicroplastics), $<5-1 \mathrm{~mm}$ (microplastics), $<25-5 \mathrm{~mm}$ (mesoplastic), and $>25 \mathrm{~mm}$ (macroplastic) [18], as shown in Fig. 1. Products resulting from mechanical, optical, chemical and biological degradation of plastic wastes can be found in the aquatic and atmospheric environment in all sizes. However, for the present investigation, we consider that microplastics that are smaller $100 \mu \mathrm{m}$, to be the one that have significant negative impact on aquatic environment and human health due to the following two reasons; a): high surface-to-volume ratio correlated with the rate of diffusion and adsorption, and b): they are not separated from water in conventional filtration and treatment systems of drinking water or in the sedimentation tanks of wastewater treatment. Presently there are limited systematic studies on models that demonstrate impact of microplastics on human health and aquatic ecosystem, while there is abundant literature on the widespread presence of (micro and micro) plastics in our environment.

Most common polymers found in aquatic environments are polyurethane, polycarbonate, polystyrene, polyvinylchloride, polyethylene and polypropylene. Due to floatability of polyethylene and polypropylene, the floating microparticles of these plastics are not isolated during water and wastewater treatment processes, because during such processes there is either a rapid filtration through sand filters with the size of sand $\sim 500-1200 \mu \mathrm{m}$ or slow sand filter with the size of sand $\sim 150-300 \mu \mathrm{m}$. Even in conjunction with activated carbon, the plastic microparticles that are less than $100 \mu \mathrm{m}$ are neither isolated from such drinking water treatment filtration processes [19], nor do they settle in the sedimentation tanks. Therefore, such particles are returned to the aquatic environment after wastewater treatment processing and are transported through the drinking water treatment plant to the water distribution system. Hence, one of the objectives is to study the concentration of microplastics with the size of less than $100 \mu \mathrm{m}$ that are floating near waterair interphase, track their transport, analyze microbial coating associated with such water pollutants, and assess potential adverse environmental impacts of these biofilm-coated neustonic microplastics.

\section{Toxicity Associated with Microplastics}

The process of disintegration and dispersion of plastic in aquatic environment and formation of fine plastic particulates, release certain additives that were added to the plastics during the manufacturing process, such as phthalates, polybrominated diphenyl ethers and alkylphenols which exhibit carcinogenic, (neuro) toxic, mutagenic and endocrine disrupting characteristics. Additionally, fine plastic particulates also result from plastics microbeads that are abundantly used in commercial facial and body scrubs, toothpastes and cosmetic products. Table 1 provides a summary of these environmental pollutants released from microplastics and their impact on human health and the environment [20-31]. This study, therefore, reviews impact of microplastic particles from $0.1 \mu \mathrm{m}$ (typical size of virus) to $100 \mu \mathrm{m}$ (corresponding to typical size of bacterial aggregates and microalgae [32]), since such floating particles will not be captured during municipality water treatment processes and hence, subsequently have the potential to pass through subsequent filtration stages and spread associated toxicity through drinking water and food supply chain.

Floating microplastics, as shown in Table 2 [3347], can also be considered as vectors for hydrophobic organic chemicals [48]. Hydrophobic pollutants of water are concentrated near water-air interphase and adsorb on hydrophobic surface of floating microplastics. The concentration of hydrophobic substances associated with microplastics, typically range on the orders of magnitude greater than surrounding seawater [49], since plastic concentration in whole ocean is $\sim 2 * 10^{-9} \mathrm{~g} / \mathrm{L}^{2}$ and as compared to $8^{*} 10^{-2} \mathrm{~g} / \mathrm{L}^{2}$ in highly contaminated rivers [50]. Microplastics are normally ingested by a wide variety of marine organisms. Ingestion may be direct or indirect via trophic transfer. Microplastic particles are often found concentrated in an organisms' digestive tracts such that bivalves, tissues and cells, having potentially adverse effects caused by physical damage or intoxication by chemicals, that are released from the microplastics [51]. It was discovered recently that the sea turtles are attracted to the smell emanating from the bio-fouled plastic and are not attracted by the smell from pure microplastic [52]. Often, microplastics are readily ingested by zooplankton, that is a food source for the secondary consumers [53]. Microplastic particles that are coated with microbial biofilm appear to be attractive feed for zooplankton, which is normally 
consumed by fish, and finally by humans through the food supply chain. Although much of the marine debris, as described before, focuses on floating plastic debris, it is important to recognize that only approximately half of all plastic is positively buoyant, which is dependent on the density of the material, due to the presence of entrapped air. Also, roughly half of seafood is farmed (e.g., aquaculture) and half is wild caught, thus seafood consumption represents one pathway for human microplastic exposure. After floating plastic debris get sufficiently fouled with biological growth that the density becomes greater than seawater, and it sinks. Despite of ongoing investigations, more datasets from similar studies are necessary to comprehend ecological significance of adsorbed hydrophobic water pollutants and its widespread challenge due to ubiquity in the environment, impacts on aquatic and marine wildlife and translocation to animal parts, typically eaten by humans, resulting in secondary exposure via the food supply chain $[15,54]$.

Many factors likely affect the absorption of microplastics, viz. size, shape, polymer, charge, hydrophobicity and physiological factors. Major toxicokinetic mechanisms are identified as endocytosis and persorption, while limited toxicodynamic data using animal studies show inflammation during liver histology and oxidative stress, energy and lipid metabolism [55]. Fig. 2 provides some guidelines on the predicted sizes for absorption and distribution in human and animal models. It is further known that microplastics with size less $20 \mu \mathrm{m}$, that are present in food would be able to penetrate into organs, while the microplastics with the sizes from $<0.1$ to $10 \mu \mathrm{m}$ would be able to access organs, penetrate through the cell membranes, the blood-brain barrier and the placenta and can cause cytotoxic effects [56]. However, the fate of microplastics in the human body after ingestion of the particles and their toxicokinetic are not well understood $[57,58]$. The problem with toxicity of microplastic particles may be considered as acute as is the case with nanoparticles [59], since both are considered as emerging environmental contaminants of global concern and their characteristics change with reduction in dimensions [60]. Our earlier investigations of nanoparticles [61] in aquatic media along with this investigation, potentially may serve as a Segway for toxicokinetic investigations for mixed pollutants in environment, including Persistent Bioaccumulative and Toxic Substances (PBTs) chemicals. Even at significantly low concentrations, PBTs can be illusive in the environment due to their ability to bio-magnify, leading to toxic effects at higher trophic levels, even though their ambient concentrations are well below toxic thresholds. A subgroup of PBTs are known as persistent organic pollutants (POPs), such as Dichlorodiphenyltrichloroethane (DDT), dioxins, and Polychlorinated biphenyl (PCBs), and are subject of our ongoing investigations.

Theoretically, toxic effects of microplastics can be explained by their very high specific surface area. For example, the plastic cubes of $10 \mu \mathrm{m}$ size has specific surface $0.67 \mathrm{~m}^{2} / \mathrm{g}$, while plastic plate of $1 \mathrm{~mm}$ thickness has the specific surface $0.001 \mathrm{~m}^{2} / \mathrm{g}$. Hence, the diffusion rate of the soluble, potentially toxic components from plastic particles with the size of $10 \mu \mathrm{m}$ could be almost 670 times higher than that for the plastic bottle, plastic film or plate. Therefore, microplastics tend to adsorb harmful substances and under stress conditions, that are known to occur during the its lifecycle, leach certain additives with endocrine disruption and carcinogenic properties [55,57]. Estrogens were the dominant endocrine disrupting chemicals (EDCs) on plastic particles and were either concentrated from the surrounding water or originated from plastic manufacturing. Bisphenol A has the highest detection frequency, followed by bisphenol $\mathrm{S}$, and consequently some plastic additives mimic estrogen, with Estradiol Equivalency Factor (EEF) $\sim 2 * 10^{-4}$ [62]. Moreover,

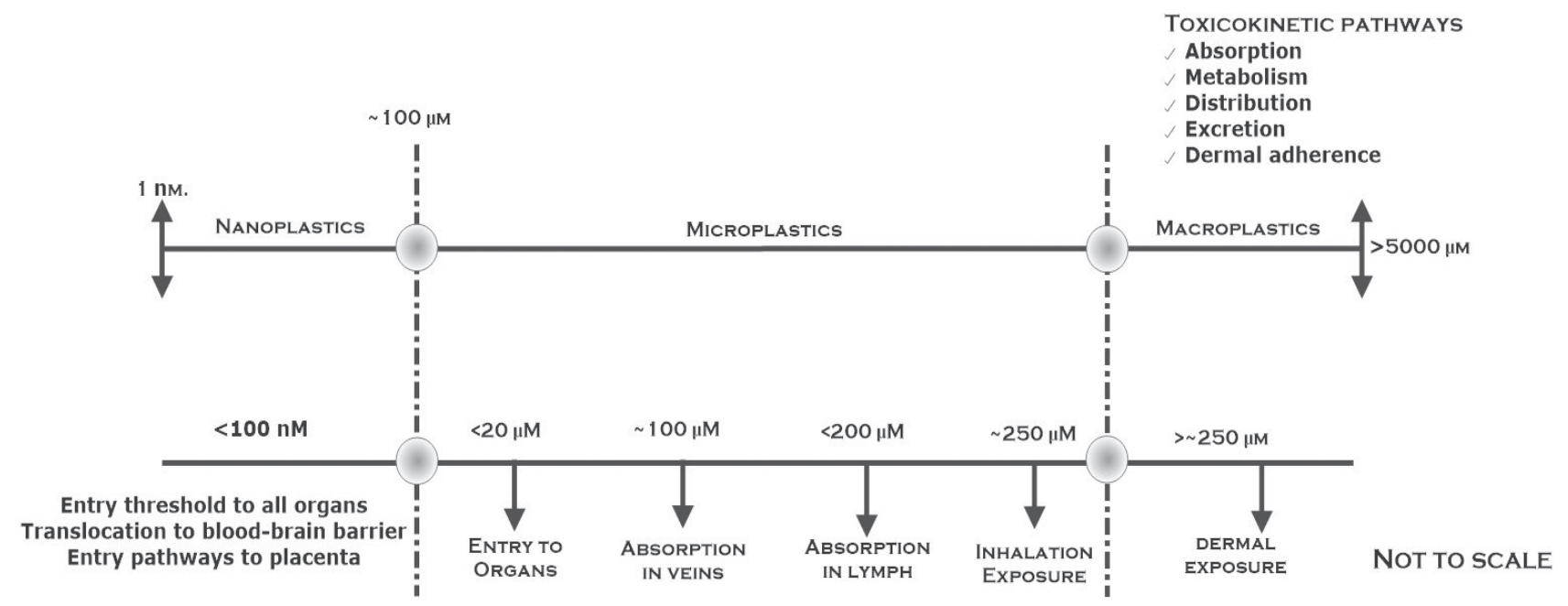

Fig. 2. Toxicokinetic pathways and dimensions of plastic debris. 
Table 1. Classes of plastics that are commonly encountered in the marine environment and their health hazard.

\begin{tabular}{|c|c|c|c|c|}
\hline $\begin{array}{l}\text { Plastic Class in Marine } \\
\text { Debris }\end{array}$ & Monomers & Additives & Adsorbed pollutants & Observed Health Hazards \\
\hline \multirow[t]{3}{*}{ Polyurethane (PUR/PU) } & Propylene oxide & & Hydrophobic & Carcinogenic [20, 21], Mutagenic [22] \\
\hline & Ethylene Oxide & & Hydrophobic & Carcinogenic [20, 21], Mutagenic [22] \\
\hline & $\begin{array}{l}\text { Toluene-2, } 4 \text {-diisocy- } \\
\text { anate (TDI) }\end{array}$ & & & Irritant [23] \\
\hline Polycarbonate (PC) & Bisphenol A & & & $\begin{array}{l}\text { Endocrine disruption [24], Effects: } \\
\text { reproductive and developmental effects } \\
{[25]}\end{array}$ \\
\hline Polystyrene (PS) & Styrene & & Hydrophobic & Genotoxic [22], Carcinogenic $[20,21]$ \\
\hline Polyvinylchloride (PVC) & Vinyl Chloride & & & Carcinogenic $[20,21]$ \\
\hline Polyethylene (PE- LD/HD) & & & Hydrophobic & Carcinogenic $[20,21]$ \\
\hline Polypropylene (PP) & & & Hydrophobic & Carcinogenic $[20,21]$ \\
\hline Phthalates & & Plasticizers & & Endocrine disruption [24] \\
\hline $\begin{array}{l}\text { Polybrominated diphenyl } \\
\text { ethers (PBDEs) }\end{array}$ & & $\begin{array}{c}\text { Flame } \\
\text { suppressant }\end{array}$ & & $\begin{array}{c}\text { Endocrine disruption [24], Carcinogenic } \\
\qquad[20,21]\end{array}$ \\
\hline Alkylphenols & & Antioxidant & & Endocrine disruption [24] \\
\hline Cellulose Acetate (CA) & & & & Carcinogenic $[20,21]$ \\
\hline Organometallic polymers & & $\begin{array}{l}\text { Alkaline } \\
\text { earth metals }\end{array}$ & & $\begin{array}{c}\text { Poisonous }[25], \text { renal }[26,27] \text { and neu- } \\
\text { rotoxicity }[28,29]\end{array}$ \\
\hline \multirow[t]{2}{*}{ Nylon } & & & & Carcinogenic $[20,21]$ \\
\hline & & & $\begin{array}{l}\text { Polycyclic aromatic } \\
\text { hydrocarbon } \\
\text { Pesticides Cadmium, } \\
\text { Chromium, Lead }\end{array}$ & $\begin{array}{l}\text { Carcinogenic }[20,21] \text {, renal }[26,27] \\
\text { and neurotoxicity }[28,29] \\
\text { Developmental effects }[25,30,31]\end{array}$ \\
\hline
\end{tabular}

smaller marine microplastics leach greater quantities of EDCs because the sorption from surrounding seawater is more efficient for smaller particles. Additionally, due to the large specific surface area, the polyethylene and polypropylene microparticles exhibit high and reversible sorption of hydrophobic pollutants from aquatic environment [63], thus making the microplastics even more toxic.

\section{Biofilm-Coated Microplastics Sources}

Microplastics are also known as carriers of colonized microorganisms. Microbial hydrophobic cells are concentrated near the water-air interphase [64-66], since they can produce biofilm of potentially pathogenic chemotrophic bacteria and toxic phototrophic cyanobacteria [67-72] on the surface of the microplastic particles. In addition to the aquatic medium, the microplastics emission, transmission and deposition also takes place through atmosphere [73] and land surface. The microplastics can travel by air as airborne pollutants, thus spreading their adverse impact via atmosphere. In an atmospheric fallout study [74], it was demonstrated that $90 \%$ of microplastics are fibers, of which $50 \%$ consist of size between 100-1000 $\mu \mathrm{m}$ and the remaining $50 \%$ are of size between $1000-5000 \mu \mathrm{m}$, consisting of polyethylene and polypropylene. It is worth noting that the majority of water-polluting microplastics also consist of polyethylene and polypropylene with lower density than water. Furthermore, hydrophobic microfibers from textiles, such as nylon and polyester, usually wash off the clothes and concentrate near waterair interphase as well, producing adverse environmental impacts. The fibers or droplets that are released into surrounding air from the water-air interphase produce "cloud" or dust, which contains microplastics, microorganisms, and hydrophobic pollutants adsorbed by microplastics from water. It is also known that cloud from water-air interphase can disperse far from the source - a distance on the order of several $\mathrm{km}$ from shores [62]. As an addition source, exposures to multiple chemicals via inhalation of microplastics through dust, ingestion of contaminated fresh water, or consumption of contaminated food could have significant adverse effects on general health than individual toxicants $[75,76]$. Therefore, a microplastic-biofilm system is likely to cause persistent and potential adverse effects on biota due to its combination with chemical and biological agents and/or antagonistic effects in pelagic and benthic environments. 
Table 2. Buoyancy of Common Microplastics.

\begin{tabular}{|c|c|c|}
\hline Water & Density $\left(\mathrm{g} / \mathrm{cm}^{3}\right)$ & \\
\hline Seawater $[33,34]$ & $1.020-1.029$ & \\
\hline Water $\left(\right.$ at $\left.10^{\circ} \mathrm{C}\right)[35,36]$ & 0.99975 & \\
\hline Rivers and Estuaries & Depends on many factors & \\
\hline Polymer & Density $\left(\mathrm{g} / \mathrm{cm}^{3}\right)$ & Flow Direction in Seawater \\
\hline Polystyrene (PS - solid) [37] & $1.04-1.50$ & Downwards* \\
\hline Polystyrene (PS - foam - expanded) ]38] & $0.01-0.05$ & Upward \\
\hline Polystyrene (PS - form - extruded) [38] & $0.03-0.05$ & Upward \\
\hline Polyethylene (PE - LD) [39] & $0.92-0.94$ & Upward \\
\hline Polyethylene (PE- HD) [39] & $0.94-0.97$ & Upward \\
\hline Polyethylene (PE - Linear LD) [39] & $0.92-0.95$ & Upward \\
\hline Polypropylene (PP) [40] & $0.88-1.23$ & Depends \\
\hline Polycarbonate (PC) [41] & $1.15-1.52$ & Downwards \\
\hline Polyvinyl chloride (PVC) [42] & $1.15-1.70$ & Downwards \\
\hline Polyamide (PA - Nylon 6) [43] & $1.13-1.38$ & Downwards \\
\hline Polyamide (PA - Nylon 6,6) [43] & $1.13-1.38$ & Downwards \\
\hline Poly methylmethacrylate (PMMA)[43] & $1.10-1.25$ & Downwards \\
\hline Polyethylene terephthalate (PET)[44] & $1.30-1.50$ & Downwards \\
\hline Polychloroprene (CR neoprene -foam) [45] & $0.11-0.56$ & Upward \\
\hline Polychloroprene (CR neoprene - solid) [46] & $1.20-1.24$ & Downwards \\
\hline Acrylonitrile Butadiene Styrene (ABS) [47] & $1.03-1.21$ & Downwards* \\
\hline
\end{tabular}

*depends on size

\section{Experimental Methods and Materials}

\section{Sampling and Analysis of Biofilm-Coated Microplastics}

There is a significant body of research describing sorption of hydrophobic microplastics by pollutants that include monocyclic and polycyclic aromatic hydrocarbons, chlorinated aromatic hydrocarbons, phenols, detergents, etc., concentrated at or near the water-air interphase. This leads to the formation of neustonic zooplankton, as carbon and energy sources are adsorbed by hydrophobic plastic microparticles, partially due to surface hydrophobicity and surface crowding. Since, microplastics with adsorbed water pollutants and bacterial cells form microlayer at or near the water-air interphase, within a thickness about 10-20 $\mu \mathrm{m}[65,77]$, it results in negative impact on ecosystems and human health through food-chain cycle as the pollution concentration can reach as much as $10^{5}$ times time their concentration in the bulk of water. Due to the reduced dimension of microplastics, sampling and analysis in aquatic environment is complex and requires several specific analytical methods [78].
Since very little data is available in terrestrial ecosystem of neustonic microplastics resulting from the most commonly used polymers, such as polyethylene and polypropylene (with density $\sim 860-950 \mathrm{~kg} / \mathrm{m}^{3}$ ) and polycarbonate (with density $\sim 1200 \mathrm{~kg} / \mathrm{m}^{3}$ ), we conducted initial investigations to characterize neustonic zooplankton at or near the waterair interphase due to these commonly used plastics in Black sea region, since in a report by the Commission on the Black Sea Against Pollution the litter around several hot spots was considered to be one of the most pressing environmental challenge. It is estimated that over $4.2 \mathrm{~T}$ of plastic debris is discarded per day by Danube alone in Black sea. For this investigation, we conducted studies of microplastics sampling near water-air interphase during autumn of 2018 - winter of 2019 in the Dnieper river estuary at the points where the river Dnieper flows into the Black Sea, as shown in Fig. 3a). The sampling was evaluated using a vacuumcollector of microplastics, as show in Fig. 3b), in which the method involves collecting a pool of water in plastic bottles with subsequent storage in the refrigerator for a $24 \mathrm{hrs}$. Water samples are also collected from waterair interphase using neustonic collector, as shown 
a)

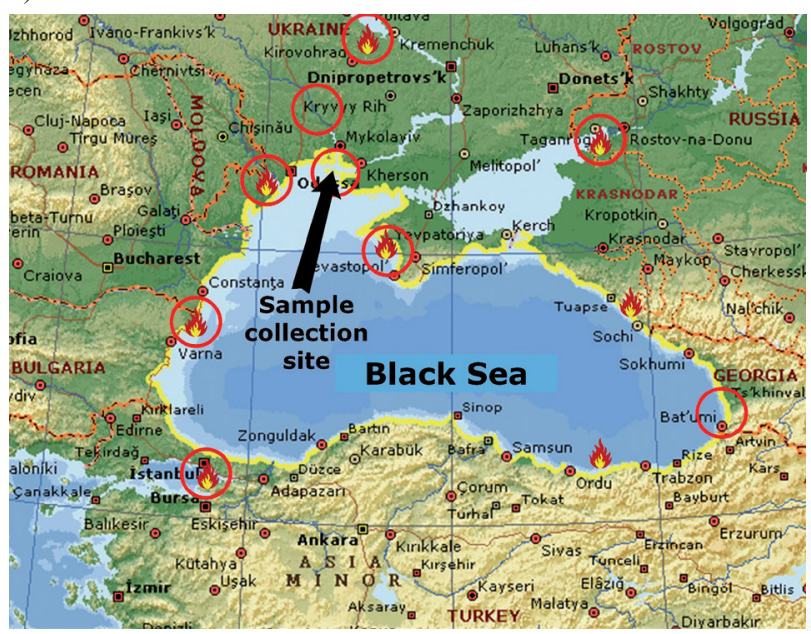

b)

Fig. 3. a) Map showing location of sample collection, future sample collection locations and marine pollution hot spots around Black sea basin, b) Vacuum-collector of microplastics near water-air interphase.

in Fig. 3b). The sample collector was prepared in our laboratory in Kiev, Ukraine, however, one of the commercial products that is normally used for collection of the neustonic microplastics, is a lower end of Millipore SX0004700 Polypropylene Swinnex membrane filter holder, fixed in Styrofoam plate it's for floatability on water surface.

Since microorganisms aggerate near waterair interphase due to hydrophobicity of the surface of bacterial cells or spores [65, 66, 77, 79], typical laboratory microscopic glass slides were used to study neuston water samples and cells, and adsorption of micro-objects in water-air interphase. Scanning electron microscope (SEM), as well as confocal laser scanning microscopy images were used to study the biofilm-coated microplastics, quantitative differentiation between the plastic particles, biocoated particles and bacterial cells, in addition to evaluation of surface hydrophobicity of bacterial cell [66]. Several samples were analyzed for optical density, as shown in Fig. 4, of hexadecane and bacterial cells formed on water-air interphase attached to vertically submerged microscope slide. The simplest method to evaluate \% of cells passed from water to hydrophobic phase is by adherence to hydrocarbons method [80], which is performed through the vortexing of bacterial suspension with the hexadecane and measuring optical density before and after the vortexing. Our investigation further demonstrated that hydrophobicity of cells of Escherichia coli is about zero, while hydrophobicity of cells of Staphylococcus aureus is 92\% [65]. However, hydrophobicity of bacterial cell surface is not a stable genetic feature, since the hydrophobicity of the cell surface can be increased from initial $10-20 \%$ to final $60-70 \%$ [65], using several passages of Bacillus thuringiensis or Pseudomonas putida from the bacterial biofilm near water-air interphase.
To study microbially-coated near-spherical plastic microparticles with sizes ranging from 0.2-35 $\mu \mathrm{m}$, while in a rapidly flowing fluid streamflow, a cytometer was used as the most suitable equipment [65] to ensure that every cell is analyzed independently. The process of surface modification is to alter the physicochemical interactions to improve the functionality of the original material. Processes, such as staining of biomaterials change cell adhesions increase biocompatibility of the material and interaction as a bioactive material for specific applications, such as measurements of the microparticle volume by side dispersion of light. The method permits determination of the ratio of biomass to plastic in microplastics and measures the concentrations of the non-coated and bio-coated particles. Confocal laser-scanning microscopy (CLSM) of the samples after staining of either protein or nucleic acid and measuring of chlorophyll using a red autofluorescence can also be used to differentiate particles coated with chemotrophic or phototrophic

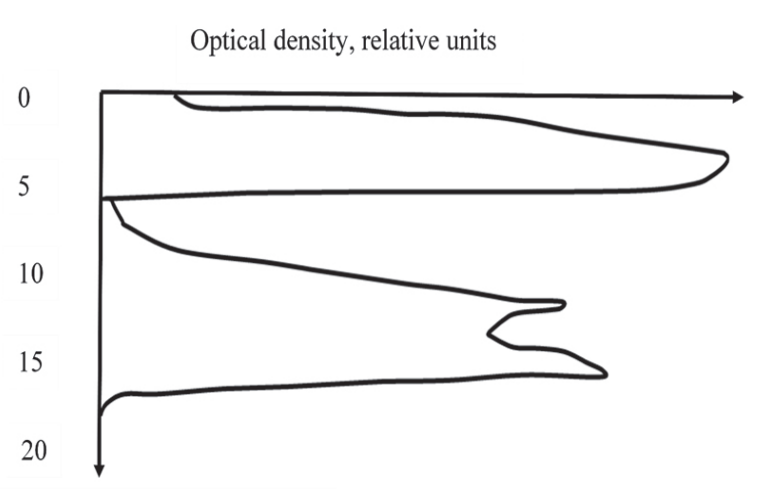

Distance from water surface, $\mu \mathrm{m}$

Fig. 4. Optical scan of three-layers film of hexadecane and bacterial cells formed on water-air interphase attached to vertically submerged microscope slide. 
microorganisms [32]. Modern particle analyzers produce data on the concentration and shapes of the microparticles in the water samples, but this equipment cannot differentiate pure plastic or bio-coated plastic microparticles.

\section{Microorganisms at the Water-Air Interphase}

Bacterial neuston is usually a thin biofilm on the inner part of air-water interphase. Biodiversity of bacterial neuston includes the distribution of bacterial species, as well as genetic variants of these species, cells within different phases of cell cycle, or different stages of the lifecycle that relate to the hydrophobicity of cell surface [79]. For example, R- and S-genetic variants of bacteria differ by pathogenic properties and by cell surface hydrophobicity. The cell surface hydrophobicity of R-variants Bacillus licheniformis, B. thuringiensis and Streptococcus sp. ranges from 3-5 times more than that of $\mathrm{S}$-variants. The Concentration of spores of the representatives of genus Bacillus sp. in water-air interphase is 2-3 orders of magnitude higher that in the bulk of water $[65$, 79]. So, microplastics from water-air interphase serve as a collector of the hydrophobic spores of putative pathogenic Bacillus cereus, B. anthracis, or other sporogenic pathogens. Hence, it is critical that accumulation of bacterial cells, plastic microparticles, as well as hydrophobic and surface-active substances in thin water-air interphase layer are accounted for monitoring of these biohazards in aquatic environment.

\section{Results and Discussion}

\section{Bio-Aggregates of Microparticles and Micro-Organisms}

There are several experimental datasets showing that microplastics released to the environment are quickly, generally within hours, colonized by microorganisms forming biofilm-coated particles [8183]. For example, bacterial colonization of low-density polyethylene microplastics for a 14-day experiment was demonstrated using scanning electron microscopy (SEM), fluorescence in situ hybridization (FISH) and quantitative polymerase chain reaction (PCR) [82]. Bacteria growing on surface microplastics were different than those in surrounding environment. After 14 days of colonization, the representatives of the genera Arcobacter and Colwellia dominated (84-93\% of sequences) in biofilm on microplastics. Probably, the cells of these bacteria were hydrophobic because it is known that the genera Arcobacter and Colwellia were previously affiliated with the degradation of hydrocarbons in marine environment [82]. SEM images and fluorescence microscopy after nucleic acid staining or after FISH showed that bacteria form biofilm over microplastics, such that the particles grew several times larger and the sizes of combined plastic and biomass particles were between $\sim 5-15 \mu \mathrm{m}$.

It was demonstrated by several researchers that plastic microparticles are vectors for harmful microorganisms and microbial toxins [70, 79]. Microbiological analysis of microplastics samples from intertidal locations around the Yangtze estuary in China showed that keystone bacteria were Rhodobacterales, Sphingomonadales and Rhizobiales [84]. The representatives of Rhodobacterales are known as the most common surface-colonizing bacteria [85]. Many representatives of Rhizobiales (formerly named Rickettsiales) are pathogens causing meningitis, fever, flu and other infectious diseases [78]. Massive DNA sequencing showed specificity of plasticadhered microorganisms, "plastisphere", were from the microbial community of the bulk water [56, 59]. Additionally, it was detected that the representatives of putative pathogenic genus Vibrio may be dispersed over long distances, by floating persistent plastics [68]. Furthermore, 23 putative pathogens were identified, mainly from genera Vibrio, Tenacibaculum, and Staphylococcus in the samples of "plastisphere" [86]. Metagenomic analyses of microplastic biofilm in river water revealed opportunistic human pathogens Pseudomonas monteilii and $P$. mendocina, and plant pathogen $P$. syringae, thus further confirming that biofilms associated with microplastics produce environmental risk and potential adverse impacts on human health [64]. Photoautotrophic cyanobacteria of the genera Phormidium and Rivularia, which are putative neurotoxic microorganisms, are common in "plastisphere" [86]. Some cyanobacteria and algae colonizing polyethylene microplastics are also known to degrade polyethylene [71].

\section{Potential Impacts of Biofilm-coated Microplastics}

It was observed that samples of the Black Sea water contained microplastics in $30 \mathrm{~cm}$ depth layer with a maximum concentration 1200 particles $/ \mathrm{m}^{3}$ [87]. However, the thickness of the layer near airwater interphase is just about $10 \mu \mathrm{m}$ [57], while the maximum concentration of floating microplastics can be $\sim 3.6 \times 10^{6}$ particles $/ \mathrm{m}^{3}$ or 360 particles $/ \mathrm{m}^{2}$ of the water-air interphase layer. Hence, to study an effect of microplastics on environment and its impact on health, the concentration of pure and plastic particles coated with bacterial cells should be measured within $10 \mu \mathrm{m}$ depth layer of water-air interphase. It is not a simple technological task and poses a technological challenge. An additional platform, that is currently being used to study the floatability of the microplastics coated with chemotrophic and/or phototrophic microorganisms and accumulation of these particles in aquatic environment is by using unmanned aerial sensor platforms, having hyperspectral imaging, Light Detection and Ranging (LIDAR) and Laser Induced Breakdown Spectroscopy 


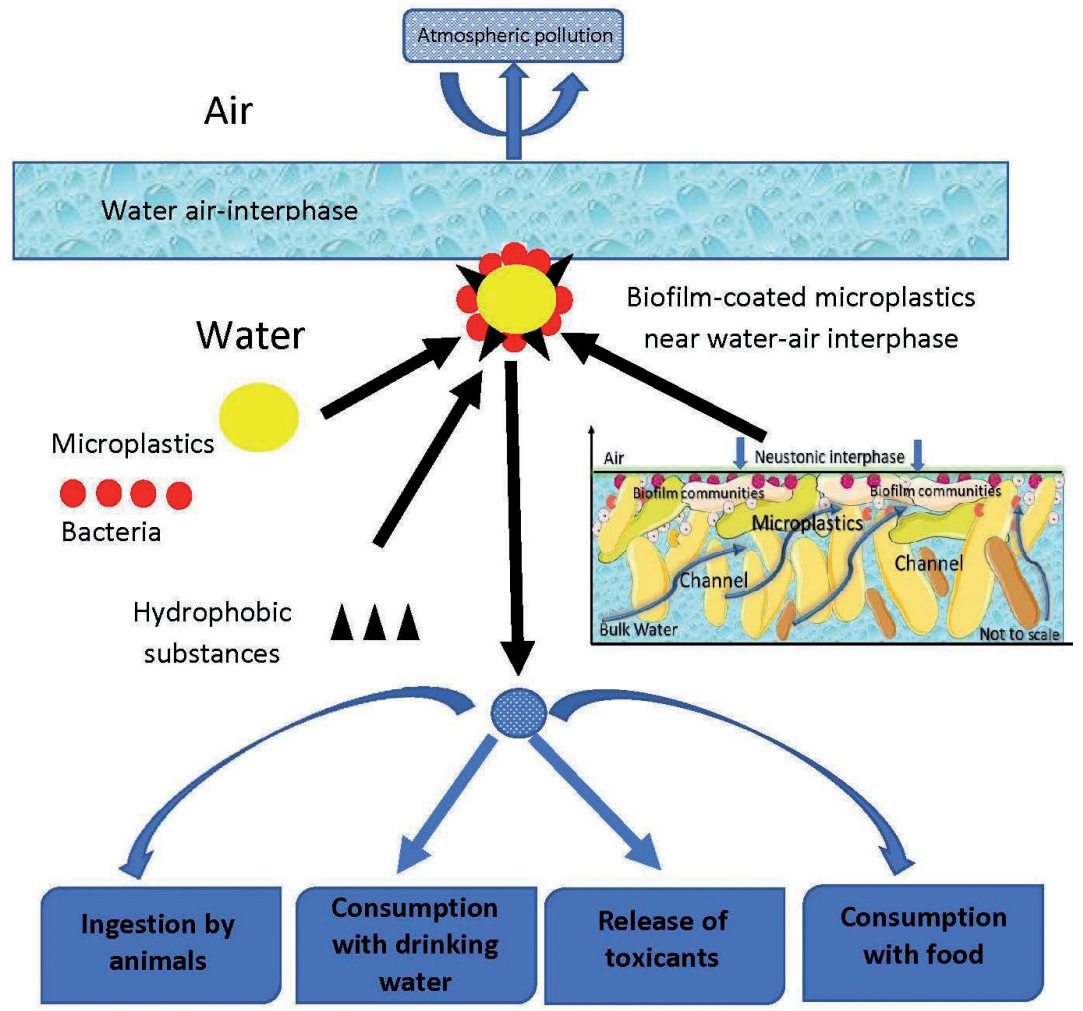

Fig. 5. Model showing formation of biofilm-coated fine microplastics.

(LIBS) capabilities [88, 89] for real-time monitoring and analysis using spectral signatures.

During water treatment, it was also noted that biofilm associated with the floating microplastic is determined to be more resistant to disinfection than suspended microbial cells [78]. Hence, water-borne pathogens of these biofilm-coated microplastics potentially can be retained in water and spread to drinking water distribution system, thus microbial biofilm associated with microplastics pose further risk for the environment and for human health [90], necessitating further studies. Pathogenic bacteria concentrating in the layers near the water-air interphase may also be considered with national security perspectives because even small quantity of hydrophobic bacterial biomass released, for example with ship's ballast water can contaminate large areas in the port [91]. Based on the results of the present study, it is concluded that (micro)plastic microparticles coated with chemotrophic or phototrophic microorganisms have potential to create neustonic bio-aggregates concentrated near thin layer of water-air interphase, as shown in the inset of Fig. 5, as a model for neustonic microplastics. Hydrophobic and often pathogenic bacteria dominate the water-air interphase as they are attached to water surface or to the hydrophobic microplastics. Impacts of even small quantity of microplastics in aquatic environment must be carefully reviewed, considering large specific surface of the microparticles, ultrathin biolayer on water-air interphase and large area of waterair interphase.

\section{Conclusions and Path Forward}

Hydrophobic water pollutants and hydrophobic, often pathogenic, bacteria dominate near water-air interphase, being attached to water surface and to the hydrophobic microplastics. Despite of growing concern of their environmental pollution, potential toxicological impacts and several governments banning singleuse plastic bottles and grocery bags, plastics remain critical to our modern way of life, due its ubiquity and widespread use in computers, cell phones, vehicles, coatings, cosmetics, and most of the life-saving advanced technologies of modern medicine. Inclusion of various forms of plastic in several hardware applications, such as insulation, paints, coating etc., and being lightweight for transportation industry to help minimize fossil fuels consumption, necessitates toxicity investigations to assess ways as how to mitigate or minimize their environmental impact. The study presented here is aimed at investigating microplastics that are concentrated in water-air interphase in fresh water or seawater ecosystems using neustonic floating biofilm-coated microplastics collected from few millimeters layer near water-air interphase. The following conclusions are drawn from this investigation.

- The problem of neustonic microplastics at the water - air interphase remains an acute engineering task, due to its significance.

- A method to collect neustonic microplastic was developed. Optical scan of three-layers film of 
hexadecane and bacterial cells formed at the waterair interphase attached to vertically submerged microscope slide was conducted as a means to identify microplastics.

- A model demonstrating bacterial cells formations was developed.

- Due to wide-spread distribution of microplastics and bacterial biofilm aggregates in freshwater and river estuaries, the study highlights a critical need of engineering and treatment of drinking water to remove these neustonic micro-aggregates. This treatment is not developed yet and is currently under investigation using magnetized nano-silica particles.

- The study further highlights use of advanced technologies for microplastics degradation, such as nano-photocatalysis, controlled biodegradation of microplastics using microorganisms, upcycling of plastics which will reduce downstream recycling, and nature-inspired solutions using biomimetics.

- Advanced sensor platforms are proposed for detection and identification of microplastics using stand-off detection.

As a future investigation, a controlled biodegradation of microplastics in wastewater treatment plants using colonizing selected microorganisms has promising results, as it has been tried for oil spills and reducing phytoplankton overgrowth [92]. Floating and hydrophilic bio-microplastics also can be removed by conventional precipitation/coagulation with the increased dosage of aluminum or calcium salts. As an example, precipitation of bio-coated microplastics from extra-thin layer of water-air interphase to the bottom sediment could, in principle, be facilitated by their reaction with hydrophobic salts of magnesium, calcium, or iron [93]. From security standpoint, pathogenic bacteria concentrating in the layer near water-air interphase must be considered in the context of technologies for prevention of bioterrorism attacks in the ports, since even a minute quantity of hydrophobic bacterial biomass released from a ship's ballast water can contaminate much larger areas in ports, as microplastic floating carriers of pathogenic bacteria hypothetically could enhance negative impacts of hydrophobic cells. Lastly, in addition to a robust lifecycle analysis, upcycling, data-driven policies and study of impacts of even small quantity of biofilmcoated microplastics on the aquatic environment, is necessary to account for safe and sustainable marine environment, food chain supply, sustainable ecosystem - all concurrent with the benefits of modern technological innovations.

\section{Conflicts of Interest}

The authors declare no conflict of interest.

\section{Acknowledgments}

The authors would like to acknowledge support provided for the research of microplastics by National University of Food Technologies, Kyiv, Ukraine.

Dedicated to Prof. Ivanov.

\section{Conflict of Interest}

The authors declare no conflict of interest.

\section{References}

1. LEBRETON L.C.M., VAN DER ZWET J., DAMSTEEG J. W., SLAT B., ANDRADY A., REISSER J. River plastic emissions to the world's oceans. Nature Communications, 8, 15611. DOI: 10.1038/ncomms15611. 2017.

2. LAMBERT S., WAGNER M., Microplastics are contaminants of emerging concern in freshwater environments: an overview. In: Freshwater Microplastics: Emerging Environmental Contaminants. M. Wagner, S. Lambert, eds., The Handbook of Environmental Chemistry, 58, 1-24. Springer Open. doi.org/10.1007/9783-319-61615-5, 2018.

3. ERIKSEN M., LEBRETON L.C.M., CARSON H.S., THIEL M., MOORE C.J., BORERRO J.C., Plastic pollution in the world's oceans: more than 5 trillion plastic pieces weighing over 250,000 tons afloat at sea. PLoS ONE, 9 (12), e111913. doi.org/10.1371/journal. pone.0111913. 2014.

4. VASEASHTA A., IVANOV V., DEKHTYAR Y., BOLGEN N., Nanomaterials Based Technologies for Identification and Mitigation of Environmental Nano/ Microplastics, NP2020-011, Nanoposter $2020-9^{\text {th }}$ Virtual Nanotechnology Conference, The International Nanoscience Community. 2020.

5. ABBASI S., SOLTANI N., KESHAVARZI B., MOORE F., TURNER A., HASSANAGHAEI M., Microplastics in different tissues of fish and prawn from the Musa Estuary, Persian Gulf. Chemosphere, 205, 80, 2018.

6. AUTA H.S., EMENIKE C.U., FAUZIAH S.H., Distribution and importance of microplastics in the marine environment: a review of the sources, fate, effects, and potential solutions. Environ. Int. 102, 165, 2017.

7. BROWNE M.A., CRUMP P., NIVEN S.J., TEUTEN E., TONKIN A., GALLOWAY T., THOMPSON R., Accumulation of microplastic on shorelines worldwide: sources and sinks. Environ. Sci. Technol. 45, 9175, 2011.

8. EERKES-MEDRANO D., THOMPSON R.C., ALDRIDGE D.C., Microplastics in freshwater systems: a review of the emerging threats, identification of knowledge gaps and prioritization of research needs. Water Res. 75, 63, 2015.

9. ROCHMAN C.M., BROOKSON C., BIKKER J., DJURIC N., EARN A., BUCCI K., ATHEY S., HUNTINGTON A., MCILWRAITH H., MUNNO K., DE FROND H., KOLOMIJECA A., ERDLE L., GRBIC J., BAYOUMI M., BORRELLE S.B., WU T., SANTORO S., WERBOWSKI L.M., ZHU X., GILES R.K., HAMILTON 
B.M., THAYSEN C., KAURA A., KLASIOS N., EAD L., KIM J., SHERLOCK C., HO A., HUNG C., Rethinking Microplastics as a Diverse Contaminant Suite, Environmental Toxicology and Chemistry, 38 (4), 703, Doi: org/10.1002/etc.4371, 2019.

10. DU J., XU S., ZHOU Q., LI H., FU L., TANG J., WANG Y., PENG X., XU Y., DU X. A review of microplastics in the aquatic environmental: distribution, transport, ecotoxicology, and toxicological mechanisms. Environmental science and pollution research international, 27 (11), 11494, 2020.

11. WU C., ZHANG K., XIONG X., Microplastic pollution in inland waters focusing on Asia. In: Freshwater Microplastics: Emerging Environmental Contaminants. M. Wagner, S. Lambert, eds., The Handbook of Environmental Chemistry, 58, 85, Springer Open. DOI: 10.1007/978-3-319-61615-5 5, 2018.

12. AYTAN U., VALENTE A., SENTURK Y., USTA R., ESENSOY SAHIN F.B., MAZLUM R.E., AGIRBAS E., First evaluation of neustonic microplastics in Black Sea waters. Mar. Environ. Res. 119, 22, 2016.

13. KAMALODIN K., ALI M. Neustonic microplastic pollution in the Persian Gulf, Marine Pollution Bulletin 150, 110665, 2020.

14. TALSNESS C.E., ANDRADE A.J.M., KURIYAMA S.N., TAYLOR J.A., VOM SAAL F.S. Components of plastic: experimental studies in animals and relevance for human health. Phil. Trans. R. Soc. B 364, 2079, DOI: 10.1098/ rstb.2008.0281, 2009.

15. LOMONACO T., MANCO E., CORTI A., LANASA J., GHIMENTI S., BIAGINI D., DIFRANCESCO F., MODUGNO F., CECCARINI A., FUOCO R., CASTELVETRO V., Release of harmful volatile organic compounds (VOCs) from photo-degraded plastic debris: A neglected source of environmental pollution. Journal of Hazardous Materials, 394, 122596. DOI: 10.1016/j. jhazmat.2020.122596, 2020.

16. ROYER S.J., FERRÓN S., WILSON S.T., KARL D.M., Production of methane and ethylene from plastic in the environment. PLOS ONE 13(8): e0200574. DOI: 10.1371/ journal.pone.0200574, 2018.

17. ROES L., PATEL M.K., WORRELL E., LUDWIG C., Preliminary evaluation of risks related to waste incineration of polymer nanocomposites. Science of Total Environment, 417, 76-86, DOI: 10.1016/j. scitotenv.2011.12.030, 2012.

18. DIEPENS N.J., KOELMANS A.A., Accumulation of Plastic Debris and Associated Contaminants in Aquatic Food Webs. Environmental Science \& Technology, 52, 15, 8510, 2018.

19. CRITTENDEN J.C., TRUSSELL R.R., HAND D. ., HOWE K.J., TCHOBANOGLOUS G., MWH's water treatment: principles and design. $3^{\text {rd }}$ Ed. Hoboken, N.J.: John Wiley \& Sons. DOI: 10.1002/9781118131473, 2012.

20. OSHA Carcinogen standards: https://www.osha.gov/SLTC/ carcinogens/standards.html, accessed: Sept. 27, 2020.

21. CDC guidance on Isocyanates: https://www.cdc.gov/ niosh/topics/isocyanates/default.html, accessed: Sept. 27, 2020.

22. EPA guidance on PBTs: https://www.epa.gov/trash-freewaters/toxicological-threats-plastic\#pbts, accessed: Sept. 27, 2020.

23. CDC guidance on TDI, 2,4-TDI, 2,4-Toluene diisocyanate: https://www.cdc.gov/niosh/npg/npgd0621.html, accessed: Sept. 27, 2020.
24. NIH guidance on Endocrine disruptors: https://www. niehs.nih.gov/health/topics/agents/endocrine/index.cfm, accessed: Sept. 27, 2020.

25. MSDS on Styrene: https://www.acplasticsinc.com/ techsheets/Styrene_MSDS.pdf, accessed: Sept. 27, 2020.

26. NIH guidance on nano sized plastics: https://www.ncbi. nlm.nih.gov/pmc/articles/PMC6863350/, accessed: Sept. 27, 2020.

27. NIH guidance for photocurable polymers: https://pubmed. ncbi.nlm.nih.gov/25725557/, accessed: Sept. 27, 2020.

28. NIH guidance on neurotoxicity of BPAs in plastics: https:// www.ncbi.nlm.nih.gov/pubmed/30953899, accessed: Sept. 27, 2020.

29. W4C guidance on neurotoxicity of additives: https:// waste4change.com/7-types-plastic-need-know/, accessed: Sept. 27, 2020.

30. GRANDJEAN P., LANDRIGAN P.J., Developmental neurotoxicity of industrial chemicals, The Lancelet, 368 (9553), 2167, doi.org/10.1016/S0140-6736(06)69665-7, 2006 www.thelancet.com/journals/lancet/article/ PIIS0140-6736(06)69665-7/fulltext, accessed: Sept. 27, 2020.

31. NIH guidance on developmental neurotoxicity of orthophthalates: https://www.ncbi.nlm.nih.gov/ pubmed/24486776, accessed: Sept. 27, 2020.

32. IVANOV V. Environmental Microbiology for Engineers. Second Edition. CRC Press, Taylor \& Francis Group. Boca Raton. 400, 2015.

33. ELERT G., Ed. The Physics Factbook. (2002), Published at: https://hypertextbook.com/facts/2002/EdwardLaValley. shtml, accessed: Sept. 27, 2020.

34. Engineering Toolbox-Sea Water Properties: https://www. engineeringtoolbox.com/sea-water-properties-d_840.html, accessed: Sept. 27, 2020.

35. Engineering Toolbox- Water Density: https://www. engineering toolbox.com/water-density-specificweight-d 595.html, accessed: Sept. 27, 2020.

36. Therm Excel- Physical Characteristics of Water: https:// www.thermexcel.com/english/tables/eau_atm.htm, accessed: Sept. 27, 2020.

37. AQUA-CALC FORUM: Density of Polystyrene: https:// www.aqua-calc.com/page/density-table/substance/ polystyrene, accessed: Sept. 27, 2020.

38. AQUA-CALC FORUM: Polystyrene Foam: https://www. aqua-calc.com/calculate/volume-to-weight/substance/ polystyrene-blank-foam, accessed: Sept. 27, 2020.

39. OMNEXUS - The Materials Selection PlatformPolyethylene (PE): https://omnexus.specialchem.com/ selection-guide/polyethylene-plastic, accessed: Sept. 27, 2020.

40. OMNEXUS - The Material Selection Platform - Density of plastics - Technical properties: https://omnexus. specialchem.com/polymer-properties/properties/density, accessed: Sept. 27, 2020.

41. AQUA-CALC FORUM: Polycarbonate: https://www.aquacalc.com/page/density-table/substance/polycarbonateblank--op-lexan-cp-, accessed: Sept. 27, 2020.

42. ENGINEERS EDGE: Properties of Plastic Materials: https://www.engineersedge.com/plastic/properties_of_ plastic_materials_14630.htm, accessed: Sept. 27, 2020.

43. SP2: Density of Polymers: https://scientificpolymer.com/ density-of-polymers-by-density/, accessed: Sept. 27, 2020.

44. Polymer Database: PMMA: http://www.polymerdatabase. com/polymers/polymethylmethacrylate.html, accessed: Sept. 27, 2020. 
45. AQUA CALC FORUM: Polyethylene terephthalate: https://www.aqua-calc.com/page/density-table/substance/ polyethylene-blank-terephthalate-blank--op-mylar-cp-, accessed: Sept. 27, 2020.

46. Polymer Database: Chloroprene: http://polymerdatabase. com/Elastomers/Chloroprene.html, accessed: Sept. 27, 2020.

47. 3D Insider: Acrylonitrile Butadiene Styrene: https://3dinsider.com/what-is-abs/, accessed: Sept. 27, 2020.

48. RIST S., HARTMANN N.B. Aquatic ecotoxicity of microplastics and nanoplastics: lessons learned from engineered nanomaterials. In: Freshwater Microplastics: Emerging Environmental Contaminants. M. WAGNER, S. LAMBERT, EDS., The Handbook of Environmental Chemistry, 58, 25-49. Springer Open. DOI: 10.1007/978-3319-61615-5 2, 2018.

49. ZICCARDI, L.M., EDGINGTON, A., HENTZ, K., KULACKI, K.J., DRISCOLL, K.S., Microplastics as vectors for bioaccumulation of hydrophobic organic chemicals in the marine environment: a state-of-thescience review. Environmental Toxicology Chemistry, 35, 1667, doi.org/10.1002/etc.3461, 2016.

50. MOORE, C.J., LATTIN, G.L., ZELLERS, A.F., Quantidades e tipos de plásticos provenientes de dois rios urbanos que escoam para águas costeiras e praias do Sul da Califórnia. Revista de Gestão Costeira Integrada, 11(1), Páginas 65-73. DOI: 10.5894/rgci194, 2011.

51. BARBOZA, L.G.A., VETHAAKD, A.D., LAVORANTE, B.R.B.O., LUNDEBYE, A. K., GUILHERMINO, L., Marine microplastic debris: an emerging issue for food security, food safety and human health. Marine Pollution Bulletin, 133, 336, DOI: 10.1016/j.marpolbul.2018.05.047, 2018.

52. PFALLER J.B., GOFORTH K.M., GIL M.A., SAVOCA M.S., LOHMANN K.J., Odors from marine plastic debris elicit foraging behavior in sea turtle. Current Biology, 30, PR213-R214. DOI: 10.1016/j.cub.2020.01.071, 2020.

53. BOTTRELL Z.L.R., BEAUMONT N., DORRINGTON T., STEINKE M., THOMPSON R.C., LINDEQUE P.K., Bioavailability and effects of microplastics on marine zooplankton: A review. Environmental Pollution, 245, 98, DOI: 10.1016/j.envpol.2018.10.065, 2019.

54. DE-LA-TORRE G.E., Microplastics: an emerging threat to food security and human health. Journal of Food Science and Technology, 57, 1601, DOI: 10.1007/s13197-019-04138-1, 2019.

55. DENG Y., ZHANG Y., Response to Uptake of microplastics and related health effects. Scientific reports 7, 46687, 2017.

56. BING, W., XIAOMEI, W., SU, L., ZHIZHI, W., LING, C., 2019. Size-dependent effects of polystyrene microplastics on cytotoxicity and efflux pump inhibition in human Caco-2 cells, Chemosphere, 221, 333, DOI: 10.1016/j. chemosphere.2019.01.056.

57. WRIGHT S.L., KELLY F.J., Plastic and human health: a micro issue? Environmental Science and Technology, 51, 6634, DOI: 10.1021/acs.est.7b00423, 2017.

58. RIST S., ALMROTH B.C., HARTMANN N.B., KARLSSON T.M., A critical perspective on early communications concerning human health aspects of microplastics. Science of Total Environment, 626, 720, DOI: 10.1016/j.scitotenv.2018.01.092, 2018.

59. VASEASHTA A. (ED.), Life Cycle Analysis of Nanoparticles: Risk, Assessment, and Sustainability.
ISBN\#: 978-1605950235, DEStech Publishers, Inc., www.destechpub.com/product/life-cycle-analysis-ofnanoparticles, accessed: Sept. 27, 2020, 2015.

60. VASEASHTA A., Technological Innovations in Sensing and Detection of Chemical, Biological, Radiological, Nuclear Threats and Ecological Terrorism, Springer. DOI: 10.1007/978-94-007-2488-4, 2012.

61. GATTI A., MONTANARI S., VASEASHTA A., Nanopathology - risk assessment of mysterious cryptogenic diseases. In book: Life Cycle Analysis of Nanoparticles - Risk, Assessment, and Sustainability, DEStech Publishers, PA. USA, 2015.

62. DRIS R., GASPERI J., ROCHER V., SAAD M., RENAULT N., TASSIN B., Microplastic contamination in an urban area: a case study in Greater Paris, Environmental Chemistry, 12 (5), 592. DOI: 10.1071/EN14167, 2015.

63. LIU X., SHI H., XIE B., DIONYSIOU D.D., ZHAO Y., Microplastics as both a sink and a source of bisphenol a in the marine environment. Environmental Science and Technology, 53, 10188, DOI: 10.1021/acs.est.9b02834, 2019.

64. PALUSElli A., FAUVELle V., GALgANI F., SEMPERE R., Phthalate release from plastic fragments and degradation in seawater. Environmental Science and Technology, 53, 166, Available at: https://hal.archivesouvertes.fr/hal-01974368. DOI: 10.1021/acs.est.8b05083, 2019.

65. STABNIKOVA E., Biodiversity of bacterial populations monitored by flow cytometry. In: Rapid Methods for Analysis of Biological Materials in the Environment. STOPA P.J., BARTOSZCZE M.A., eds., NATO ASI Series 2000, 30. Springer, Dordrecht. DOI: 10.1007/978-94-0159534-6 14, 2000.

66. KACZOREK E., PACHOLAK A., ZDARTA A., SMULEK $\mathrm{W}$, The Impact of biosurfactants on microbial cell properties leading to hydrocarbon bioavailability increase. Colloids Interfaces, 2, 35. DOI: 10.3390/colloids2030035, 2018.

67. DANG H., LI T., CHEN M., HUANG G., Cross-ocean distribution of Rhodobacterales bacteria as primary surface colonizers in temperate coastal marine waters. Applied and Environmental Microbiology, 74, 52, DOI: 10.1128/AEM.01400-07, 2008.

68. SCHMUTZHARD E., HELBOK R., Rickettsiae, protozoa, and opisthokonta/metazoa. Neurology, 121, 1403, DOI: 10.1016/B978-0-7020-4088-7.00096-1, 2014.

69. DUSSUD C., HUDEC C., GEORGE M., FABRE P., HIGGS P., BRUZAUD S., Colonization of nonbiodegradable and biodegradable plastics by marine microorganisms. Frontiers in Microbiology, 9, 1571. DOI: 10.3389/fmicb.2018.01571, 2018.

70. OBERBECKMANN S., MARTINL L.G.J., MATTHIAS L., Marine microplastic-associated biofilms - a review. Environmental Chemistry, 12, 551, DOI: 10.1071/ EN15069, 2015.

71. SARMAH P., ROUT J., Role of algae and cyanobacteria in bioremediation: prospects in polyethylene biodegradation. In Advances in Cyanobacterial Biology, 333-349. Elsevier Pub. Eds. Singh, P.K., et al. DOI: 10.1016/B978-0-12819311-2.00022-X, 2020.

72. WU X., PAN P., LI M., LI Y., BARTLAM M., WANG Y. Selective enrichment of bacterial pathogens by microplastic biofilm. Water Research, 165, 114979. DOI: 10.1016/j.watres.2019.114979, 2019.

73. YAMASHITA K., YAMAMOTO N., MIZUKOSHI A., NOGUCHI M., NI. Y., YANAGISAWA Y., Compositions 
of Volatile Organic Compounds Emitted from Melted Virgin and Waste Plastic Pellets, Journal of the Air \& Waste Management Association, 59 (3), 273, DOI: 10.3155/1047-3289.59.3.273, 2009.

74. CAI L., WANG J., PENG J. ZHI T., ZHIWEI Z., CHE Q., Characteristic of microplastics in the atmospheric fallout from Dongguan city, China: preliminary research and first evidence. Environmental Science and Pollution Research, 24, 24928, DOI: 10.1007/s11356-017-0116-x, 2017.

75. WALLACE D.R., Environmental pesticides and heavy metals - role in breast cancer. In: Toxicity and Hazard of Agrochemicals. Marcelo L. Larramendy and Sonia Soloneski, eds. IntechOpen: Available at: www.intechopen. com/books. accessed: Sept. 27, 2020, DOI: 10.5772/60779, 2015.

76. HERNANDEZ A.F., BUHA A., CONSTANTIN C., WALLACE D.R., SARIGIANNIS D., NEAGU M., ANTONIJEVIC B., WALLACE H.A., WILKS M.F., TSATSAKIS A., Critical assessment and integration of separate lines of evidence for risk assessment of chemical mixtures. Archives of Toxicology, 93, 2741, DOI: 10.1007/ s00204-019-02547-x, 2019.

77. BAS S., KRAMER M., STOPR D., Biofilm surface density determines biocide effectiveness. Frontiers in Microbiology, 8, 2443, DOI: 10.3389/fmicb.2017.02443, 2017.

78. KLEIN S., DIMZON I.K., EUBELER J., KNEPPER T.P. Analysis, occurrence, and degradation of microplastics in the aqueous environment. In: Freshwater Microplastics: Emerging Environmental Contaminants. M. Wagner, S. Lambert, eds. The Handbook of Environmental Chemistry, 58, 51, Springer Open. DOI: 10.1007/978-3319-61615-5_3, 2018.

79. IVANOV V. Monitoring the bacterial neuston. In: Rapid Methods for Analysis of Biological Materials in the Environment, in STOPA P.J., BARTOSZCZE M.A., eds. NATO ASI Series, 30, 67-72. Springer, Dordrecht. DOI: 10.1007/978-94-015-9534-6 5, 2000.

80. ROSENBERG M., GUTNICK D., ROSENBERG E., Adherence of bacteria to hydrocarbons: A simple method for measuring cell-surface hydrophobicity. FEMS Microbiology Letters, 9, 29, 1980.

81. JACQUIN J., CHENG J., ODOBEL C., PANDIN C., CONAN P., PUJO-PAY M., BARBE V., MEISTERTZHEIM A.L., GHIGLIONE J.-F., Microbial ecotoxicology of marine plastic debris: a review on colonization and biodegradation by the "plastisphere". Frontiers in Microbiology, 10, 865, DOI: 10.3389/ fmicb.2019.00865, 2019.

82. HARRISON J.P., SCHRATZBERGER M., SAPP M., OSBORN A.M., Rapid bacterial colonization of lowdensity polyethylene microplastics in coastal sediment microcosms. BMC Microbiology, 14, 232, DOI: 10.1186/ s12866-014-0232-4, 2014.

83. HARRISON J.P., HOELLEIN T.J., SAPP M., TAGG A.S., YON J.-N., J. OJEDA J.J. Microplastic-associated biofilms: a comparison of freshwater and marine environments. In: Freshwater Microplastics: Emerging Environmental Contaminants (M. Wagner, S. Lambert, eds.). The Handbook of Environmental Chemistry, 58, 181, Springer Open. DOI:10.1007/978-3-319-61615-5_3, 2018.
84. JIANG P., ZHAO S., ZHU L., LI D. Microplasticassociated bacterial assemblages in the intertidal zone of the Yangtze Estuary. Science of The Total Environment, 624, 48, DOI: 10.1016/j.scitotenv.2017.12.105, 2018.

85. DANG H., LI T., CHEN M., HUANG G., Cross-ocean distribution of Rhodobacterales bacteria as primary surface colonizers in temperate coastal marine waters. Applied and Environmental Microbiology, 74, 52, DOI: 10.1128/AEM.01400-07, 2008.

86. ZETTLER E.R., MINCER T.J., AMARAL-ZETTLER L.A. Life in the "Plastisphere": microbial communities on plastic marine debris. Environmental Science and Technology, 47, 7137, DOI: 10.1021/es401288x, 2013.

87. VERESHCHAKA A.L., ANOKHINA L.L., The benthoneuston of the Black Sea: Composition and environmental factors influencing its nocturnal dynamic, Continental Shelf Research, 140, 60, DOI: 10.1016/j.csr.2017.04.007, 2017.

88. VASEASHTA A., Emerging sensor technologies for monitoring water quality. In: Applications of Nanomaterials for Water Quality. Bart Van der Bruggen, Ed. Future Science Ltd, 66, DOI: 10.4155/9781909453074, 2013.

89. VASEASHTA A., Cyber-physical systems - nanomaterial sensors based unmanned aerial platforms for real-time monitoring and analysis. In: $4^{\text {th }}$ International Conference on Nanotechnologies and Biomedical Engineering, 685, DOI: 10.1007/978-3-030-31866-6_121, 2019.

90. SCHERER S., WEBER A., LAMMBERT S., WAGNER M. Interactions of microplastics with freshwater biota. In: Freshwater Microplastics: Emerging Environmental Contaminants, in WAGNER M., LAMBERT S., Eds.). The Handbook of Environmental Chemistry, 58, 153, Springer Open. DOI: 10.1007/978-3-319-61615-5_3, 2018.

91. IVANOV V. The technologies for prevention of bioterrorism attacks in the ports. In: Proceedings of $5^{\text {th }}$ Maritime Security Workshop. Temasek Defence Systems Institute and Lawrence Livermore National Laboratory, 4-7 Dec. Singapore 2007.

92. KUBE M., CHERNIKOVA T.N., AL-RAMAHI Y., BELOQUI A., LOPEZ-CORTEZ N., GUAZZARONI M.E., HEIPIEPER H.J., KLAGES S., KOTSYURBENKO O.R., LANGER I., NECHITAYLO T.Y., LÜNSDORF H., FERNÁNDEZ M., JUÁREZ S., CIORDIA S., SINGER A., KAGAN O., EGOROVA O., PETIT P.A., STOGIOS P., KIM Y., TCHIGVINTSEV A., FLICK R., DENARO R., GENOVESE M., ALBAR J.P., REVA O.N., MARTÍNEZGOMARIZ M., TRAN H., FERRER M., SAVCHENKO A., YAKUNIN A.F., YAKIMOV M.M., GOLYSHINA O.V., REINHARDT R., GOLYSHIN, P.N., Genome sequence and functional genomic analysis of the oildegrading bacterium Oleispira antarctica. Nat. Commun. 4, 2156, doi: 10.1038/ncomms3156. PMID: 23877221; PMCID: PMC3759055. 2013.

93. STABNIKOV V., IVANOV V., VASEASHTA A., Biotechnological immobilization of chemical, biological and radioactive pollutants on land and infrastructure demolition waste after industrial accident, military action or terrorist attack. In: Bio-Based Materials and Biotechnologies for Eco-Efficient Construction, in TORGAL F.P., TSANG D., IVANOV V., Eds., Elsevier, 377, 2020. 
